Jurnal Maksipreneur | Vol. 8 No. 2 | June 2019 | p. 165 - 180

\title{
The Effect of Macroeconomic Fundamentals on the Financial Performance with Deposits as Intervening Variables: A Case Study of Sharia Banks in Indonesia
}

\section{Sri Hermuningsih}

Management Department, Universitas Sarjanawiyata Tamansiswa Yogyakarta, Indonesia Author correspondence: hermun_feust@yahoo.co.id

\begin{abstract}
The aim of this research is to determine the effect of macroeconomic fundamentals on financial performance with deposits as intervening variables in sharia banking in Indonesia. The research of macroeconomic fundamentals in the banking sector is an important component for improving the bank's financial performance. The research samples were all sharia public banks of year 2014 until 2017. By using purposive sampling method, data analysis in this research applied Partial Least Square. The results of this research indicated that macroeconomic fundamentals and deposits have a positive effect on financial performance. The results of the study have some implications for policies which can help to improve the performance of the sharia banking sector.
\end{abstract}

Keywords: Macroeconomic fundamentals, deposits, financial performance, sharia banking.

Abstrak. Tujuan dari penelitian ini adalah untuk mengetahui pengaruh fundamental ekonomi makro terhadap kinerja keuangan dengan deposito sebagai variabel intervening pada perbankan syariah di Indonesia. Studi tentang fundamental ekonomi makro di sektor perbankan merupakan komponen penting dalam peningkatan kinerja keuangan bank. Sampel penelitian adalah semua bank umum syariah untuk periode tahun 2014 sampai 2017. Dengan menggunakan metode purposive sampling, Analisis data menggunakan Partial Least Square. Hasil penelitian ini menunjukkan bahwa fundamental ekonomi makro dan deposito berpengaruh positif terhadap kinerja keuangan. Hasil studi tersebut memiliki beberapa implikasi terhadap kebijakan yang membantu meningkatkan kinerja sektor perbankan.

Kata kunci: Fundamental ekonomi makro, deposito, kinerja keuangan, perbankan syariah.

Article Info:

Received: October 19, 2018

DOI: http://dx.doi.org/10.30588/jmp.v8i2.416
Accepted: April 2, 2019

Available Online: May 4, 2019 


\section{BACKGROUND}

A performance reflects an institution's ability to manage and allocate its resources, so performance becomes an important thing that every institution needs to achieve. The performance of banks in general is a description of the achievements which is achieved by banks in their operations. The bank's financial performance is a description of the bank's financial conditions for a certain period, whether it covers the fund raising aspects or its fund distributions. The performance shows anything related to the strengths and weaknesses of a company.

A bank performance can be measured by analyzing and evaluating its financial statements. The financial position and financial performance information in the past is often used as a basis for predicting future financial and performance positions and other things which immediately attract the attention of users, such as dividend payments, wages, securities price movements, and the ability of the company to fulfill its commitments when it matures. The performance of sharia banking in Indonesia during 2014-2016 is shown in Table 1 below.

Table 1. CAMEL (CAR, Assets, Management, Earning, Liquidity) Ratio of Sharia Banks, Year 2014-2016

\begin{tabular}{cccccc}
\hline Year & $\begin{array}{c}\text { CAR } \\
\text { (Capital } \\
\text { Adequacy } \\
\text { Ratio) }\end{array}$ & Assets & Management & Earning & Liquidity \\
\hline 2014 & 42.07 & 19.54 & 6.80 & 111.62 & 59.19 \\
\hline 2015 & 56.98 & 20.25 & 6.21 & 132.44 & 47.52 \\
\hline 2016 & 59.61 & 28.37 & 9.04 & 154.24 & 57.65 \\
\hline 2017 & 43.13 & 15.12 & 6.01 & 94.07 & 15.02 \\
\hline
\end{tabular}

Source: BI data, modified.

Data in Table 1 show CAR, Assets, Management, Earning, and Liquidity of sharia banks for 4 (four) consecutive years, i.e. 2014-2017 which experienced some increases. The CAR increased by 14.9136 percent and 2.625994 percent, but it declined in 2015 to 2016 by -16.4778 percent. The assets increased by 0.711516 percent and 8.122918 percent, in 2015 to 2016 declined by -13.2533 percent. The management in 2014 to 2015 decreased by -0.59492 percent, in 2014 to 2015 it increased by 2,829235 percent; 2015 to 2016 declined by -3.03075 percent. In 2014 to 2015 , the earnings increased by 20.81229 percent, and 21.79994 percent while 2015 to 2016 declined by -60.1708 percent. The liquidity in 2014 to 2015 declined by -11.6697 percent, in 2014 to year 2015 it increased by 0.101213 percent and 2015 to 2016 by -0.42622 .

A country's economic fundamentals can alter the mechanism of supply and demand for the currency. Market participants have a desire to make transactions for the purposes of their life. The transactions made by society continuously on a foreign currency may lead to changes in the demand mechanisms and foreign currency offerings. The transactions in large quantities can lead to sustained changes in foreign exchange rates within a country. 
Deposits, often referred to as time deposits, are similar type of a bank service for saving offered to the public. Funds in deposits are guaranted by the government through the Deposit Insurance Corporation (LPS or Lembaga Penjamin Simpanan) on certain conditions. Deposits are depository products in a bank with a deposit system which the withdrawal can only be made after a certain time. Deposits usually have a certain period in which the money should not be withdrawn by customers. New deposits can be withdrawn on the maturity date. Generally, deposits have a maturity time of $1,3,6$, or 12 months. If the deposit is withdrawn before the due date, it will be subject to a penalty in accordance with the policy of the bank concerned. Deposits can also be automatically renewed using the ARO (Automatic Roll Over) system. Deposits will be renewed automatically after its maturity, until the owner withdraws his/her deposits. Based on the description of the background, the researchers are interested in conducting this research. The aim of this research is to determine the effect of macroeconomic fundamentals on financial performance with deposits as intervening variables in sharia banking in Indonesia.

\section{THEORETICAL REVIEW}

\section{Macroeconomic Fundamentals}

Economic fundamentals in the economic sense are two basic economic welfare arguments. First, it states that any competition based on equilibrium or Walrasian balance leads to Pareto efficiency in resource allocation. Second, it relates to state intervention, i.e. any efficient allocations that can be sustained with a competitive equilibrium. Though, they look symmetrical, the first proposition is much more common than the second one which is weaker and requires further assumptions.

The first theory is often taken to be Adam Smith's confirmatory analysis of the "invisible hand" hypothesis in a market competition which tends toward the efficiency of resource allocation. The supporting for non-intervention case in ideal conditions - let the market work and the results will be found in Pareto efficiency. However, Pareto efficiency is not necessarily the same thing as the desire or even it is more general than the definition of "efficiency" which only shows that no one can be made more prosperous without sacrifice from the other side. There are many possibilities derived from Pareto efficiency in resource allocation and not all of them may be equally desired by the community.

In ideal conditions, collectively known as Perfect Competition but never exists in the real world, as Stiglitz's proposition, for example, states that in the face of either imperfect information or incomplete markets, the Pareto efficiency market will not work. Thus, most markets in the world economy according to the viewpoint of ideal variation conditions should become the policy choice factors.

The second theory which states that both of infinity possibilities of Pareto efficiency can be attained by certain results of making the lump-the amount of gained wealth then letting the market take over. The case appears to intervene in order to get a position in the legitimate policy, redistribution, in order to help to choose efficiently among all the results which have other desired features, such as distribution of equity. However, it is also unclear how in every real world it allows the government to do some sort of redistribution. The

Jurnal Maksipreneur | Vol. 8 No. 2 | June 2019 
transfer of the lump sum will be difficult to enforce and almost never occurs to the economy since the tax is changed in the relative remuneration of the factors of production causing distortion in the production structure. In addition, the government must have perfect knowledge of consumers and the preference of the company's production function (which would never exist to choose for transferring correctly). And, this therapy can not be expected to work if many people do not understand economics, and how to effectively create to use of any transfer they received. Macroeconomic fundamentals consist of four indicators, namely inflation, interest rate, USD exchange rate, and money supply.

\section{Inflation}

Inflation is a process of increasing prices in general and continuously in relation to market mechanisms which can be caused by various factors, among others: increased public consumption, excessive liquidity in markets triggering consumption or even speculation, and to the lack of goods distribution. In other words, inflation is also a process of declining currency values continuously. Inflation is the process of an event, not the high nor low level of price. That is the price level which is considered high does not necessarily indicate inflation. Inflation is an indicator to see the rate of change, and is perceived to occur if the price rising process is continuous and mutually influential.

The term of inflation is also used to refer to an increase in money supply which is sometimes seen as the cause of price increased. There are many ways to measure the inflation rate, the two most commonly used are CPI (Consumer Price Index) and the GDP (Gross Domestic Product) Deflator. Inflation can be classified into four groups, namely: mild, moderate, severe, and hyperinflation. Mild inflation occurs when the price increase is below $10 \%$ a year; moderate inflation is in between $10 \%-30 \%$ a year; severe is in between $30 \%-100 \%$ a year; and hyperinflation or uncontrolled inflation occurs when price increase is above $100 \%$ a year. To find the inflation data can be formulated as follows:

$$
\text { IHK }(\text { Indeks Harga Konsumen })=\frac{\text { Current Price }}{\text { Basic annual price }} \text { X 100\% }
$$

\section{Interest Rate of SBI (Sertifikat Bank Indonesia)}

Interest rate of SBI or BI (the Central Bank of Indonesia) Rate is a policy rate reflecting the stance of monetary policy stipulated by Bank Indonesia and is announced to the public (Bank Indonesia, 2019). BI Rate is announced by the Board of Bank Indonesia Governors during the monthly meeting of the board and implemented in monetary operations conducted by Bank Indonesia through liquidity management in the money market to achieve the operational targets of monetary policy. The operational targets of monetary policy are reflected in the development of the Overnight Interbank Money Market Rate. The movement in the interbank money market rate is expected to be followed by an increase in deposit rates, and in turn in loan rates for banks. Taking into account other factors in the economy, Bank Indonesia will generally raise BI Rate if future inflation is expected to surpass targets which have been set. 
On the contrary, Bank Indonesia will decrease BI Rate if future inflation is predicted to fall below the established target. Bank Indonesia strengthened the monetary operations framework by introducing the new BI rate or BI 7-Day Repo Rate, which would be effective on August 19, 2016. In addition to the current BI Rate, the introduction of the new policy rate does not change the monetary policy stance being applied. Data used for the research are data which have been published by Bank Indonesia and Central Bureau of Statistics with the measurement unit of percentage (\%). The method of calculating the Interest Rate which explained its relation with the inflation, and the formula is based on Irving Fisher in Irmawati (2017) which is being used up to now. The formula is as follows:

$$
(1+i)=(1+r)(1+P E) \text { or } \quad i=r+E I+r(E I)
$$

Remarked:

i $\quad$ Nominal Interest Rate

$\mathrm{r} \quad=$ Real Interest Rate

EI $=$ Expected Inflation.

Many factors influence the interest rate, i.e. the determination of the interest rate depends on how much the domestic money market experiences the openness of a country's fund system. It also means that the determination of the financial determination of a country tends to be different. Some factors affecting the interest rate in a country are the interest rate abroad and the depreciation of domestic currency against foreign currency which is expected to occur. However, a bank determining the interest rate depends on the interaction between interest on the deposits and loan rates which are mutually affecting each other and the interest rate policy in addition to other factors.

\section{Foreign Exchange Rate}

The foreign exchange rate is the ratio of value between a currency to another currency. It means that the exchange rate shows the comparison between the values of two different currencies. Exchange rate is the value of a currency if it is exchanged with other currencies. This means that the value of a currency is determined by the exchange rate of the currency against the foreign currency. The main factors affecting demand for foreign exchange (Simorangkir \& Suseno, 2004:6) are:

a. Import payment factor. The higher the import of goods and services is, the greater the demand for foreign exchange will be. So the exchange rate will tend to weakened. Conversely, if imports decline, then demand for foreign exchange decreases to encourage the strengthening of the exchange rate.

b. Outflow capital factor. The greater the capital outflow is, the greater the demand for foreign exchange will be and in the future it will weaken the exchange rate. Capital outflow involves repayment of Indonesians' (both private and government) loan to foreigners and placement of Indonesians' capital overseas.

c. Speculation activities. The more speculative foreign exchange activity performed by speculators is, the greater the demand for foreign exchange will be; thus weakening the exchange rate of local currency against foreign currencies. 


\section{Amount of Money Supply}

The money supply in the narrow sense $\left(\mathrm{M}_{1}\right)$ is defined as the purchasing power which can be directly used for payment, it can be expanded and included in any means of payment "approaching" the money, such as time deposits and saving deposits in the banks. Money which is deposited in time deposits and savings deposits, is actually a potential purchasing power for the owner, although not as easy as cash or checks to use it (Boediono, 1994).

$$
\mathrm{M}_{1}=\mathrm{C}+\mathrm{DD}
$$

Remarked:

$\mathrm{M}_{1}=$ money supply in narrow sense

$\mathrm{C}=$ Currency

$\mathrm{DD}=$ Demand Deposits.

Demand deposits (DD) only covers the public account balances/giro deposits held by general public deposited in the bank. While the balance of bank accounts owned by a bank in another bank or central bank (Bank Indonesia) or the balance of a government-owned bank account in a bank or central bank is not included in the definition of DD. Another important thing to understand about the DD is that what the meant here is the balance or money belonging to the community that still exists in the bank and has not been used by the owner to pay/shop. The definition of money in circulation in the broader sense is $\mathrm{M}_{3}$, which includes all time deposits (TD) and saving balance (SD), large amount, rupiah or foreign currency owned by residents at banks by non-bank financial institutions. All TD and SD are called quasi money.

$$
\mathbf{M}_{3}=\mathbf{M}_{2}+\mathbf{Q M}
$$

Remarked:

$\mathrm{M}_{3}=$ money market fund

$\mathrm{M}_{2}=$ money supply

$\mathrm{QM}=$ quasi money.

In a country with a free foreign exchange system (which means that everyone can own and trade foreign exchange freely), like Indonesia, there is very little difference between TD and SD in rupiah and TD and SD in dollars. Every time you need dollars, you can buy directly into the bank, or vice versa. If you need rupiahs, you can sell directly to the bank. In this case, the difference between $\mathrm{M}_{2}$ and $\mathrm{M}_{3}$ becomes unclear. TD and SD in dollars belonging to non-residents are not included in the definition of quasi money (Boediono, 1994).

\section{The effect of macroeconomic fundamentals on deposit}

Macroeconomic fundamentals consist of four indicators, namely: inflation, interest rate, US exchange rate, and money supply. In this research, inflation is a process of price increase in general and continuously related to market mechanism that can be caused by various factors, such as increased public consumption or lack of goods distribution (Cahyono, 2009). The most commonly indicator is used to regulate the inflation rate is the Consumer Price Index (CPI). Inflation does not affect the amount of deposits. The customers of sharia banks are not affected by inflation in Indonesia. 
This can also be due to the inflation conditions which are ups and downs. They find difficulties to choose other investments than deposits, because the investments elsewhere are likely to have a higher risk than the risk of impairment inflation. While the interest rate in question is the interest rate on SBI, where SBI is a Central Bank instrument as a lender of the resort which is only used if the banks are pressed. The amount of discount facility is adjusted to the amount of funds available in the community. In this case, SBI can be interpreted as an instrument of monetary contraction that can be used by Bank Indonesia if the monetary situation is considered expansive (Rahardjo, 1995). The results of this research are in line with Yunita (2008) which shows that during an inflation, interest rate have a negative and insignificant effect on Mudharabah Deposits.

Foreign exchange rate according to Dahlan (2001) is the price of a currency stated in the price of another currency. For example, the rupiah exchange rate to US dollar shows the value of rupiah required for each US dollar. The exchange rate is a measurement of the value of a currency from another currency perspective. In line with changing economic conditions the exchange rate can also change substantially (Madura, 2000: 86). Changes in exchange rates have a negative effect on the financial performance of a company. This means that if the value of foreign currency rises then the income of a bank will go down, because the high foreign exchange prices trading on the JSE (Jakarta Stock Exchange) will be more lethargic. This research is supported by Muttaqiena (2013) which states that the exchange rate negatively affects the deposits.

\section{Deposits influence on financial performance}

Deposits are deposits of third parties to banks in which the withdrawal may only be made within a specified period according to the agreement between the third party and the bank concerned and the withdrawal shall be in accordance with the mutually agreement. According to Alper and Adem (2011), one source of bank funding is deposits. The high number of deposits distributed will affect the interest margin and profit. Adrianti (2015) and Ayu (2012) in this research revealed that the deposit positively affects the rentability of banks. The positive coefficient indicates that if the deposits increase then the bank's reantability also increases and the bank's financial performance will be good, but it depends on the extent to which the bank is able to convert the deposit obligations into credit, so the bank will get the income from the deposit.

\section{The effect of macroeconomic fundamentals on financial performance}

Inflation is an increase in the price of goods in general and continuously (Sukirno, 2000). While Morris and Morris (1999) defines inflation as an increase of the price of goods and services in general, continuous, and sustainable. This indicates that the rising inflation rate will affect the bank's operational expenses which will also increase. According to Islamic scholars, inflation has a very bad effect on the economy because it weakens the spirit of saving and attitudes toward saving from society which results in reduced desire of people to save in banks (decrease of Marginal Propensity to Save). The results of this research support the research conducted by Abduh and Idrees (2013) which aims to determine the factors which affect the financial performance of Islamic banks in 
Malaysia. The research shows that macroeconomic variables, namely inflation, have a negative impact on financial performance.

Interest rate is a policy reflecting monetary policy stance stipulated by Bank Indonesia and announced to the public. BI Rate is an indication of the short-term interest rate that Bank Indonesia wants in order to achieve the inflation target. Furthermore, if the interest rate is relatively low when compared with the interest rate abroad, it will reduce the public interest to save and encourage the flow of funds from within the country so that the banks will find it difficult in obtaining funds. But in the business sector, it will increase the potential of investment and production activities because low interest rates will increase banking credit (Pohan, 2008:54). Meanwhile, according to Supriyanti (2009:17), BI rate is not too dominant in affecting Return on Assets (ROA). High inflation, however, resulted in a rise in BI rate and resulted in banks incurring higher operating costs and affecting bank profitability. This is because prospective customers will be more interested in banks that offer higher interest rates. Meanwhile, according to Sahara (2013), BI Rate has a negative effect on Return on Assets (ROA) of sharia banks in Indonesia. This means that the increase in $\mathrm{BI}$ interest rates will be followed by the increase in conventional savings interest rates which cause customers to move their funds from sharia banks to conventional banks. In addition, the rise in conventional bank interest rates will affect the operational activities of Islamic banks in terms of financing and channeling of funds, so that the income and profit of sharia banks will be decline (Karim, 2006:255).

The exchange rate is the ratio of the exchange rate of a country's currency to a foreign currency or the ratio of the inter-country exchange rate (Hasibuan, 2011). The exchange rate represents the exchange rate of one currency to another and is used in transactions, such as international trade transactions, tourism, international investment, or short-term cash flow between countries. The smaller the income earned by banks is the declining value of the bank's financial performance will be, which means that the ability of banks to generate profits will decrease. Based on the above description, it is assumed that the exchange rate has a negative effect on financial performance. The research is in line with Kandir (2008), which found that exchange rates have a negative impact on financial performance whereas according to Oxelheim and Wihlborg (1991), which uses quarterly changes in total cashflows, commercial cash flow and sales revenue serve as dependent variables on corporate risk. It showed that a company's finance are affected by changes in the exchange rate at a moderate level.

\section{Hypothesis}

Based on the background and literature review, it can be taken temporary answers or hypothesis, namely:

H1: Macroeconomic fundamentals have a negative and significant effect on deposits.

H2: Deposits have a positive and significant impact on financial performance.

H3: Macroeconomic fundamentals have a negative and significant effect on financial performance framework.

The framework of this research is presented in Figure 1 below. 


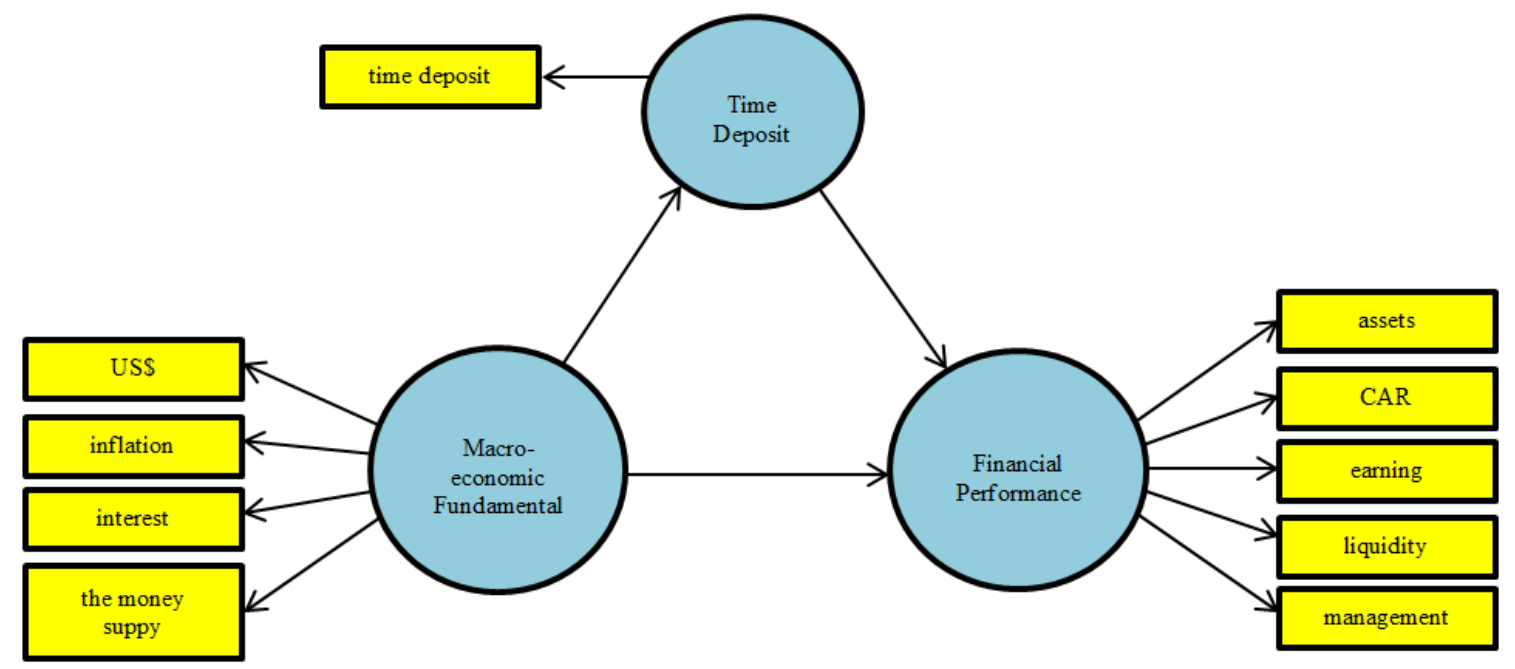

Figure 1. The Research Framework

\section{METHOD AND ANALYSIS}

\section{Data and Sample}

The samples of this research were determined with purposive sampling. The samples were 10 sharia banks in 2014-2017.

\section{Research Variables}

\section{Endogenous Variables}

An endogenous variable is a variable whose value is influenced by other variables in the model, also known as the dependent variables. The endogenous variables in this research are financial performance. Sharia financial performance can be calculated with:

a) Capital factor

Capital is one of the most vital and very important ratios to support business development and mitigate the risk of loss that may be taken by the bank. In running its operations, the bank is very dependent on the capital it has. One of the financial ratios used to calculate capital adequacy is known as Capital Adequacy Ratio (CAR). Bank Indonesia as a banking regulator in Indonesia has issued Regulation No. 3/2/PBI/2001 and No. 8/PBI/2006 concerning the change of conventional bank business activities into a commercial bank running its business based on sharia principles which sets minimum CAR of $8 \%$. For CAR which is below $8 \%$ then the bank concerned must add some capital. CAR calculation formula is as follows:

$$
\mathrm{CAR}=\frac{\text { Capital }}{\text { ATMR }} \times 100 \%
$$


Remarked:

CAR = capital adequacy ratio

ATMR = fixed assets according to risk.

b) Assets Quality

Assets quality is the quality of bank loan/bank credit where the credit has the potential to become stuck. This research applies Assets to Loan Ratio to measure the amount of channeled credit with assets owned by banks. The Assets to Loan Ratio (ALR) formula is as follows:

$$
\mathrm{ALR}=\frac{\text { Total Loans }}{\text { Total Assets }} \mathrm{X} 100 \%
$$

Remarked:

$\mathrm{ALR}=$ assets to loan ratio.

c) Management Aspect

In this case, the aspects assessed are capital management, asset quality management, general management, profitability management, and liquidity management. This research applies ROE Ratio.The ROE formula is as follows:

$$
\mathrm{ROE}=\frac{\text { Net Income }}{\text { Equity Income }} \mathrm{X} 100 \%
$$

Remarked:

ROE $=$ Return On Equity

d) Earning Aspect (Rentability)

Reantablity is an important capability for a company because it is not only as one of the health indicators of the financial aspect. The earning (rentability) aspect on bank assessment can be proxied with Net Profit Margin (NPM). NPM can be formulated as follows:

$$
\mathrm{NPM}=\frac{\text { Net Income }}{\text { Operating Income }} \times 100 \%
$$

Remarked

$\mathrm{NPM}=$ net profit margin.

e) Liquidity Aspect

A bank is considered as liquid if the bank concerned can fulfill its debt obligations, be able to pay back all of its deposits, and meet the demand for credit submitted without suspension. The indicator which is used in this aspect of liquidity is quick ratio. This ratio is to determine the ability of banks in refinancing their obligations to customers who save funds with cash assets they have. Quick ratio formula is as follows:

$$
\mathrm{QR}=\frac{\text { Cash asset }}{\text { Total Deposit }} \mathrm{X} 100 \%
$$

Remarked

$\mathrm{QR}=$ quick ratio. 


\section{Exogenous variables}

An exogenous variable is a variable whose value is not influenced by other variables in the model, known as an independent variable. Exogenous variables in this research are macroeconomic fundamentals.

\section{Intervening variable}

The intervening variable in this research is deposit. The deposits are deposits of third parties to banks in which the withdrawal may only be made within a certain period of time according to the agreement between the third party and the bank concerned and the withdrawal shall be in accordance with the mutually agreement.

\section{Structural Equation 1}

A model to illustrate the effect of Macro Economic Fundamentals is as follows:

$$
\text { Dep saving }=\gamma 1 \mathrm{Mac} \text { Ec Fund }+\varepsilon_{1}
$$

Remarked:

$$
\begin{array}{ll}
\text { Dep saving } & =\text { Deposit saving } \\
\text { Mac Ec Fund } & =\text { Macro Economy Fundamental } \\
\varepsilon_{1} & =\text { Residual on Deposit saving } \\
\gamma & =\text { Coefficient of exogenous variable influence to endogenous variable } \\
\beta & =\text { Coefficient of endogenous variable influence to exogenous variable. }
\end{array}
$$

\section{Structural Equation 2}

A model to illustrate the effect of Macroeconomic Fundamentals, Deposits savings to Financial Performance is as follows:

$$
\text { Financial performance }=\alpha \text { Mac Ec Fund }+\beta_{1} \text { Dep saving }+\varepsilon_{2}
$$

Remarked:

Dep saving

$\varepsilon_{2} \quad=$ Residual on financial performance

$\alpha=$ Coefficient of exogenous variable influence to endogenous variable

$\beta=$ Coefficient of endogenous variable influence to endogenous variable.

\section{Path Analysis}

This research applies path analysis of Structural Equation Modeling (SEM) as data analysis method. Here are some PLS Assessment Criteria used to test whether or not a model is accepted shown in Table 2 below. 
Table 2. Assessment Criteria

\begin{tabular}{cll}
\hline No & \multicolumn{1}{c}{ Criteria } & \multicolumn{1}{c}{ Remark } \\
\hline 1 & Evaluation of measurement models & a. The loading factor value is above 0.50 \\
$\begin{array}{l}\text { a. Convergen Validity } \\
\text { b. Discriminant Validity }\end{array}$ & b. Each indicator has a higher loading factor for its \\
c. Composite Reability & construct compared to other construct \\
\hline 2 & $\begin{array}{l}\text { Evaluation of structural model } \\
\text { a. R2 for endogenous latent variables } \\
\text { b. Estimation of path coefficients }\end{array}$ & a. The result of R2 is declared as significant if P \\
& & balue, 0,05
\end{tabular}

Source: Gendro (2011).

\section{RESULT AND DISCUSSION}

\section{Fit Model Evaluation}

\section{Outer Model Assessment or Measurement Model}

The research applies the limit of loading factor of 0.5 so it is said to meet the convergent validity if the loading factor value on each item $>0.50$. Processing results using SmartPLS is presented in the following figure and table.

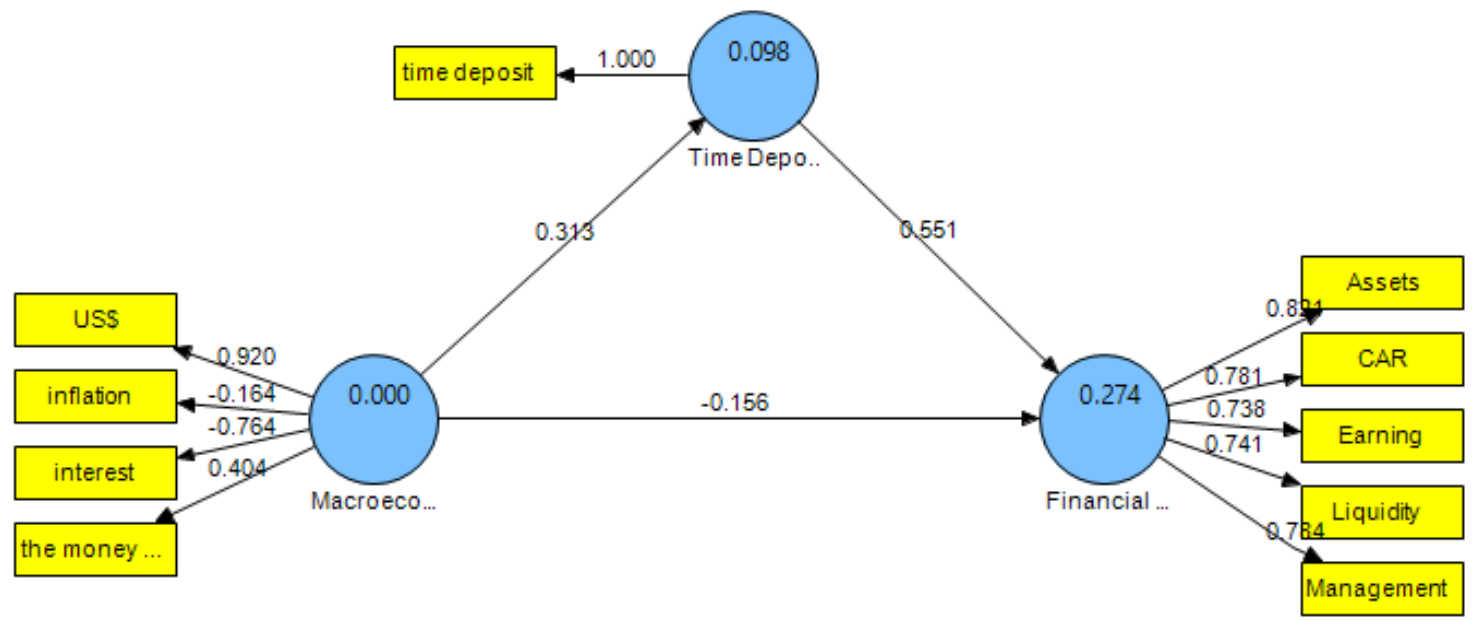

Figure 1. Structural Model 1

The above results show that there are 3 items in Macroeconomic Fundamentals variables which have factor loading value of $<0.05$ i.e. inflation, interest and money supply with values of $-0.164,-0,764$, and 0.403 . Since the loading factor value is < 0.05 , it must be removed from the model. Results after inflation, interest and the money supply are excluded from the model is presented in the following figure and table. 


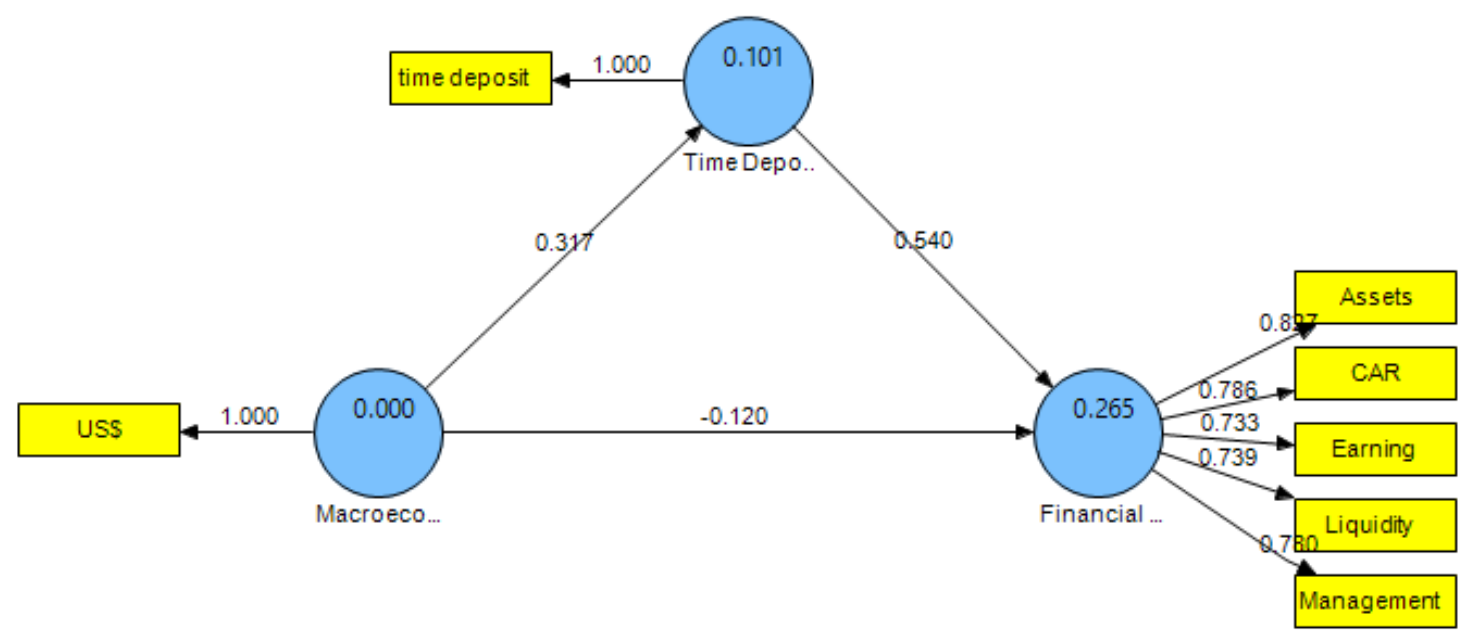

Figure 2. Structural Model 2

The above results indicate that the correlation between the indicator and the variable in the research has met the convergent validity because all of them have value factors above 0.50 .

\section{Structural Model Assessment}

Table 2 below shows that the R-square value for the time deposit variable is 0.101 . It indicates that time deposit variable is explained by the Macroeconomic Fundamentals variable of $10.1 \%$. While the R-square value for the Financial Performance variable is 0.265 which means that the Financial Performance variable is explained by the Macroeconomic Fundamentals variable and the time deposit is $26.5 \%$.

Table 2. R-Square Value

\begin{tabular}{ll}
\hline & R Square \\
\hline Financial Performance & 0.264636 \\
\hline Macroeconomic Fundamentals & \\
\hline Time Deposit & 0.100546 \\
\hline
\end{tabular}

Evaluation of the next construct model is done by calculating Q-square predictive relevance as follows:

$$
\begin{aligned}
\mathrm{Q}^{2} & =1-\left(1-\mathrm{R}_{\text {time deposit }}{ }^{2}\right)\left(1-\mathrm{R}_{\text {financial performance }}{ }^{2}\right) \\
& =1-(1-0,101)(1-0,265) \\
& =1-(0,899)(0,735) \\
& =1-0,661 \\
& =0,339
\end{aligned}
$$

Based on these calculations, the value of Q2 obtained by 0.339 indicates that the model formed is still not suitable. 


\section{Hypothesis Testing}

To test the proposed hypothesis, we can see the value of t-statistics. The result of tstatistic estimation can be seen on the result of inner weight which is presented in the following table.

Table 3. Path Coefficients (Mean, STDEV, T-Values)

\begin{tabular}{|c|c|c|c|c|c|}
\hline & $\begin{array}{c}\text { Original } \\
\text { Sample }(0)\end{array}$ & $\begin{array}{c}\text { Sample } \\
\text { Mean (M) }\end{array}$ & $\begin{array}{l}\text { Standard } \\
\text { Deviation } \\
\text { (STDEV) }\end{array}$ & $\begin{array}{c}\text { Standard } \\
\text { Error } \\
\text { (STERR) }\end{array}$ & $\begin{array}{l}\text { T Statistics } \\
(\mid \text { O/STERR } \mid)\end{array}$ \\
\hline $\begin{array}{l}\text { Macroeconomic Fundamentals } \geq \\
\text { Financial Performance }\end{array}$ & -0.119742 & -0.135065 & 0.171791 & 0.171791 & 0.697023 \\
\hline $\begin{array}{l}\text { Macroeconomic Fundamentals } \geq \\
\text { Time Deposit }\end{array}$ & 0.317089 & 0.315602 & 0.138028 & 0.138028 & 2.297290 \\
\hline $\begin{array}{l}\text { Time Deposit } \geq \text { Financial } \\
\text { Performance }\end{array}$ & 0.539706 & 0.560983 & 0.089596 & 0.089596 & 6.023769 \\
\hline
\end{tabular}

Based on Table 3 the research hypothesis is tested. The hypothesis testing uses significance level $5 \%$ with $\mathrm{t}$ table equal to $2,023(\mathrm{~N}=40)$.

\section{H1: Macroeconomic Fundamentals influence Time Deposit}

The result of coefficient parameter test between Macroeconomic Fundamentals and Time Deposit shows coefficient value of 0.317 and t value counted of 2,297. At the level of significance $(\alpha)=0.05$, the value of $t$ arithmetic is greater than the value of $\mathrm{t}$ table of 2.023. This indicates that Macroeconomic Fundamentals have a positive effect on Time Deposit. This means that the higher the Macroeconomic Fundamentals (American exchange rate) is, the higher the Time Deposit rate will become. The research hypothesis stating that Macroeconomic Fundamentals have a negative and significant effect on Time Deposit is not proven.

\section{H2: Time Deposit influences Financial Performance}

The result of parameter coefficient between Time Deposit and Financial Performance shows coefficient value equal to 0,540 and $t$ value counted equal to 6,024 . At the level of significance $(\alpha)=0.05$, the value of $t$ arithmetic is greater than the value of $t$ table of 2.023. This shows that Time Deposit has positive effect on Financial Performance. The research hypothesis stating that Time Deposit has a positive and significant impact on the Financial Performance is proven.

\section{H3: Macroeconomic Fundamentals influence Financial Performance}

The result of parameter coefficient test between Macroeconomic Fundamentals and Financial Performance shows the coefficient value equal to - 0,120 and $t$ value counted as 0,697 . At the level of significance $(\alpha)=0.05$, the value of $t$ arithmetic is smaller than the value of $t$ table of 2.023. This shows that Macroeconomic Funda- 
mentals have no effect on Financial Performance. The research hypothesis stating that Macroeconomic Fundamentals have a positive and significant effect on Financial Performance is not proven

\section{CONCLUSIONS AND RECOMENDATIONS}

\section{Conclusions}

1. Coefficient value equal to $0,317>0,05, \mathrm{t}$ value counted to 2,297 which is higher than $\mathrm{t}$ table value 2,023. This result shows that Macroeconomic Fundamentals positively affecting Time Deposit is not significant. This indicates that Macroeconomic Fundamentals have a positive effect on Time Deposit. This means that the higher the Macroeconomic Fundamentals (American exchange rate) is the higher the Time Deposit rate will be. The research hypothesis (H1) stating Macroeconomic Fundamentals have a negative and significant effect on Time Deposit is not proven.

2. The coefficient value of $0,540>0,05$ and $t$ value counted equal to 6,024 is higher than $t$ table value which is equal to 2,023. This result shows that Time Deposit has positive effect on Financial Performance. The research hypothesis (H2) stating that Time Deposit has a positive and significant impact on the Financial Performance is proven.

3. The coefficient value which is equal to $-0,120<0,05$ and $t$ value counted equal to 0,697 is lower than $t$ table value of 2.023. This result shows that Macroeconomic Fundamentals have no effect on Financial Performance. The research hypothesis (H3) stating that Macroeconomic Fundamentals have a positive and significant effect on Financial Performance is not proven.

\section{Recommendations}

The result of the research shows that the hypothesis is not proven, so for the next researchers it is suggested that they pay attention to indicators of macro economy fundamentals. Other indicators can be added, such as crude oil price or other variables such as saving and giro.

\section{References}

Abduh, M. \& Idrees, Y. (2013). Determinants of Islamic Banking Profitability in Malaysia. Australian Journal of Basic and Applied Sciences, 7(2): 204-210.

Alper, D. \& Adem, A. (2011). Bank Specific and Macroeconomic Determinants of Commercial Bank Profitability: Emprical Evidence From Turkey. Journal Business and Economics, 2(2).

Adrianti (2015). Pengaruh Tabungan, Deposito dan Kredit Modal Kerja Terhadap Rentabilitas Pada BPR di Batam Periode 2011-2014. Skripsi. Universitas Maritim Raja Ali Haji, Tanjungpinang.

Ayu, D. G. (2012). Pengaruh Tabungan dan Deposito Terhadap Rentabilitas Pada Bank Umum. Jurnal Program Studi Perbankan, Universitas Gunadarma. 
Bank Indonesia (2019). Operasi Moneter: Suku Bunga Sertifikat Bank Indonesia. Diakses tanggal 29 April 2019, https://www.bi.go.id/id/moneter/operasi/suku-bunga-sbi/ Default.aspx.

Dahlan, S. (2001). Manajemen Lembaga Keuangan. Edisi Ketiga. Jakarta: Lembaga Penerbit Fakultas Ekonomi Universitas Indonesia.

Gendro, W. (2011). Merancang Penelitian Bisnis dengan Alat Analisis SPSS 17.0 \& Smart PLS 2.0. Yogyakarta: Percetakan STIM YKPM.

Hasibuan, M. (2011). Dasar-Dasar Perbankan. Jakarta: PT Bumi Aksara.

Karim, A. A. (2006). Ekonomi Makro Islam. Jakarta: PT Rajagrafindo Perseda.

Kandir, S. Y. (2008). Macroeconomic Variables, Firm Characteristics, and Stock Returns: Evidence from Turkey. International Research Journal of Finance and Economics, 16.

Morris, K. M. \& Morris, V. B. (1999). The Wall Street Journal Guide to Understand Money and Investing. New York: Lightbulb Press.

Muttaqiena, A. (2013). Analisis Pengaruh PDB, Inflasi, Tingkat Bunga, dan Nilai Tukar Terhadap Dana Pihak Ketiga Perbankan Syariah di Indonesia 2008-2012. Economics Development Analysis Journal, 2(3).

Oxelheim, L. \& C. G. Wihlborg (1991). Corporate Strategies in a Turbulent World Economy. Management International Review, 31(4): 293-315.

Pohan, A. (2008). Potret Kebijakan Moneter Indonesia. Jakarta: PT. Raja Grafindo Persada.

Rahardjo, M. D. (1995). Bank Indonesia: Dalam Kilasan Sejarah Bangsa. Jakarta: LP3ES.

Sahara, A. Y. (2013). Analisis Pengaruh Inflasi, Suku Bunga BI dan Produk Domestik Bruto terhadap Return on Assets (ROA) Bank Syariah di Indonesia. Jurnal Ilmu Universitas Negeri Surabaya, 1(1): 149-157.

Simorangkir, I. \& Suseno (2004). Sistem dan Kebijakan Nilai Tukar, Seri Kebanksentralan No. 12. Jakarta: Pusat Pendidikan dan Studi Kebanksentralan Bank Indonesia (PPSK $\mathrm{BI})$.

Supriyanti, N. (2009). Analisis Pengaruh Inflasi dan Suku Bunga BI terhadap Kinerja Keuangan PT Bank Mandiri, Tbk. Berdasarkan Rasio Keuangan. Jakarta: Universitas Gunadarma.

Sukirno, S. (2000). Makro Ekonomi Modern: Perkembangan Pemikiran dari Klasik hingga Keynesian Baru. Jakarta: PT Raja Grafindo Persada.

Yunita, P. (2008). Faktor-faktor yang Mempengaruhi Dana Pihak Ketiga pada Perbankan Syariah. Jakarta: Universitas Indonesia. 